\title{
Reflexões sobre o jogo em Sagarana, de Guimarães Rosa
}

\author{
Edson Santos de Oliveira (UFMG / COLTEC)
}

\section{Resumo}

O presente artigo tem como objetivo fazer algumas reflexões sobre a obra Sagarana, de Guimarães Rosa, a partir da noção de jogo. Essa atividade assume algumas variantes na primeira obra rosiana, manifestando-se ora nas referências ao baralho (jogo de truco) ao xadrez ou até mesmo nos fragmentos de contos de fadas, narrativas populares e cantigas, sendo essas três últimas variantes recriadas ao longo da estória por um narrador lúdico, que lança mão da oralidade como forma arcaica do contar, rompendo com a racionalidade e apostando no faz de conta. A escrita rosiana de Sagarana se constrói na encenação ficcional do jogo, seja como estratégia dos personagens para reelaborarem os desafios do sertão-mundo, seja como brinquedo de palavras utilizado pelo narrador-autor, num processo gozoso e poético de linguagem capaz de associar a percepção infantil do mundo à psicologia do rústico. Não há no escritor mineiro apenas uma temática lúdica, mas o próprio modo de narrar se apresenta também como jogo de linguagem.

Palavras-chave: Jogo; Sagarana; Guimarães Rosa; Linguagem.

\begin{abstract}
The present article aims at making some reflections about the work Sagarana, by Guimarães Rosa, from the perspective of game. This activity takes some variants in the first Rosian work, manifesting itself in the references to the card game (Truco game), to the chess game, and even in the fragments of fairy tales, popular narratives, and songs; the latter three were recreated throughout the story by a playful narrator, which makes use of orality as an archaic way of telling, breaking with rationality and betting on the make-believe. The Rosian writing of Sagarana is built in the fictional staging of game, either as a characters' strategy to redraw the challenges of the hinterland-world, or as a wordplay used by the narrator-author in a joyful and poetic language process. There is not only a playful thematic in the mineiro writer, but the very way of narrating presents itself also as a language game.
\end{abstract}

Keywords: Play; Sagarana; Guimarães Rosa; Language. 
A noção de jogo já foi estudada por vários pesquisadores e está relacionado a diversos campos da atividade humana como a estética, a psicanálise, a pedagogia, a guerra e a poesia, para ficarmos apenas em algumas áreas. Inicialmente o jogo foi tratado como mera atividade pueril, sem ser levado a sério (DUFLO, 1999). Na Grécia foi enfocado pela sua autossuficiência: segundo Aristóteles, quem joga busca o prazer pelo próprio jogo. No século XVIII, foi discriminado pela igreja, uma vez que era tido como fonte de prazer e por isso deveria ser banido, mantendo apenas o espírito lúdico nas cerimônias religiosas. Um dos responsáveis pela revalidação do jogo na área educacional foi Rousseau, com sua obra Emílio (VELOSO e SÁ, 2007, p. 02). Na filosofia, Schiller, em suas cartas sobre a educação estética, aponta o jogo como um dos traços fundamentais do ser humano, relacionando-o ao belo, tendo em si o princípio da unidade, harmonia, legalidade e liberdade: "O homem não joga senão quando na plena acepção da palavra ele é homem, e não é totalmente homem senão quando joga" (SCHILLER, apud VELOSO e SÁ, 2007, p. 02).

Segundo Vigotsky, na aparência de um jogar existe uma atividade fundamental: o desenvolvimento cognitivo, social, emocional e psicológico (VIGOTSKY, 1979, p. 45). Afirma ainda o mesmo pensador que no jogo é que aparecem os primeiros indícios de uma capacidade típica do homem: o poder de imaginar: "Brincando, a criança cria situações fictícias, transformando com algumas ações o significado de alguns objetos" (VIGOTSKY, 1991, p.122).

Um dos maiores teóricos do jogo foi Johan Huizinga em sua obra Homo Ludens. O pesquisador flamengo define o jogo como:

Uma atividade livre, conscientemente tomada como 'não - séria' e exterior à vida habitual, mas ao mesmo tempo capaz de absorver o jogador de maneira intensa e total. É uma atividade desligada de todo e qualquer interesse material, com a qual não se pode obter qualquer lucro, praticada dentro de limites espaciais e temporais próprios, segundo certa ordem e certas regras (HUIZINGA, 2007, p. 16).

A tese de Huizinga é que o jogo precedeu a cultura. Trata-se de uma atividade livre, gratuita, desligada de um interesse material, condicionada a algumas regras, com capacidade de seduzir o jogador de forma intensa (HUIZINGA, 2007,p.16). $\mathrm{O}$ jogo não se prende à racionalidade e um de seus traços é a intensidade. Embora tenha regras delimitadas, é marcado pela liberdade e está relacionado ao ócio e ao faz de conta. Nesse sentido, o jogo, desafiando a lógica e estando sintonizado com o ficcional, está estreitamente relacionado à infância e à arte.

Freud fez algumas reflexões sobre o jogo observando o brinquedo do neto com um carretel. No estudo do psicanalis- 
ta austríaco, pode-se deduzir que a criança joga antes mesmo de estruturar as palavras. No infante, o imaginário se mostra através do ludismo, precedendo o aparecimento do simbólico. Ao brincar, o neto de Freud jogava, longe do berço, o carretel, amarrado a um barbante, trazendo-o de volta. A repetição desse movimento era acompanhada das palavras "fort-da, "foi-se", e "apareceu", "voltou”. Essa brincadeira ocorria após a ausência da mãe do menino. Quando ela retornava, ele dizia "dá" (regressou). Esse episódio foi importante para Freud perceber que o jogo poderia ser usado como forma de elaborar as perdas. A repetição do jogo é fundamental e surge assim que a mãe desaparece. Pode-se perceber nesse processo uma semelhança com a ficção, como propõe Suzi Sperber, na leitura que faz do texto freudiano: "A repetição deve ser vista como jogo representativo, que começa como reação -passiva - a uma dor, mas que termina como conquista - ativa - de resolução da dor, de sua transformação em outra coisa: ficção" (SPERBER, s/d,p. 03).

Também Lacan, em algumas passagens de sua obra, lança mão do jogo e afirma que "brincar ou jogar é a possibilidade de salto ao simbólico e a partir daí fazer borda ao real. Portanto, no jogo, articulam-se o simbólico e o real" (LACAN, apud LOPES, 2007, p. 17).

A noção de jogo é ainda estudada pelo filósofo Giorgio Agamben (AGAMBEN, 2005). O pensador italiano afirma que o homem moderno não consegue mais fazer experiência, mas apenas experimento, já que o conhecimento acabou sufocando o imaginário em benefício de uma visão cartesiana de mundo. A experiência deixou de ser essencialmente humana. Ela supõe uma abertura para o novo, uma ruptura com o mundo das certezas, uma aposta na imaginação, na singularidade. Nesse sentido é que Agamben propõe uma visão lúdica e "infantil” de mundo, rompendo com a concepção racional da ciência moderna. Infância aqui deve ser entendida não como mera etapa cronológica, mas como potência capaz de romper com a racionalidade, desafiando o previsível. Agamben pretende resgatar o laço entre experiência e linguagem. O homem só se constrói como um ser que fala. Apostando numa descontinuidade da história, o filósofo italiano mostra que através da infância é possível perceber o descompasso entre língua e discurso, natureza e cultura.

Parece-nos que a proposta agambeniana tem sintonia com a visão freudiana de jogo. Se, como afirma Suzi Sperber, ao comentar o jogo do fort-da, a repetição deve ser entendida como jogo representativo ativo, transformando a dor e a perda em ficção, o pensador italiano nos ensina que pelo jogo reinventamos o mundo. Diferentemente do rito que segue à risca o calendário, pondo uma ordem no caos, o jogo, na concepção agambeniana, transforma a rigidez temporal em um evento maleável. Nesse sentido, ele é ativo e se aproxima mais da ficção. 
Enquanto Huizinga nos apresenta uma visão cultural do jogo, parece-nos que Freud, Lacan e Agamben nos levam a pensar na atividade lúdica como essencialmente simbólica. Sendo assim, é possível encontrar um denominador comum entre infância, jogo e ficção. Na infância, o homem joga e nessa atividade recria um outro mundo, propõe uma experiência (e não um experimento), transforma, como afirma Agamben, sincronia em diacronia, reinventando experiências e desconstruindo a história.

Em Guimarães Rosa, o jogo se apresenta como uma das inúmeras possibilidades de leitura de sua obra. O crítico Flávio Loureiro Chaves demonstra que o elemento lúdico é uma constante nas estórias do escritor mineiro:

(...) Em qualquer uma das suas narrativas se faz evidente a importância atribuída ao jogo na ação das personagens e é bem assim notável que o comportamento lúdico tenha, finalmente, se transformado no princípio estético de seu programa literário, orientando o próprio ato da criação. Jogar com as palavras, segundo ele (Guimarães Rosa) diz, vem a ser uma maneira de "desencantá-las, isto é, liberar o potencial simbólico contido na língua, reconduzindo-a ao significado originário para revelar o enigma de que são portadoras (CHAVES, 1978, p. 82).

Jogar com as palavras, em Guimarães Rosa, significa revitalizá-las, reinventá-las, buscar a língua em seu estado adâmico, livre da tirania gramatical, captá-la em seu inacabamento estrutural. É nessa linha que deveríamos entender as "estórias" de Rosa. Para ele, como afirma no livro Tutameia, "A estória não quer ser história. A estória, em rigor, deve ser contra a História. A estória, às vezes, quer-se um pouco parecida à anedota." (ROSA, 1976, p. 03). É nessa linha de pensamento que Vânia Resende afirma:

O universo rosiano tem especificidade e contém rumos inaugurais; daí, ser estória e não história (que dá continuidade à ordem conhecida). A coerência desse universo repousa nas fronteiras do imaginário e o seu sentido só se atinge pelo supra-senso; faz um corte com a expectativa habitual e se impõe como um corpo estranho que fica à margem ou acima do plano da convenção. ( RESENDE, 1988, p. 26)

No sertão rosiano, através da oralidade, o sertanejo e a criança, via mitos infantis e estórias da cultura popular, reelaboram o mundo, transformando as perdas em ficção, desafiando a coerência da realidade. Afirma ainda a mesma autora citada anteriormente:

A noção de Guimarães Rosa de que o mecanismo dos mitos apresenta 'formulação sensificadora e concretizante, 
de malhas para captar o incognoscível' elucida ainda mais, os efeitos que o escritor explora ao por em função o seu conceito de arte o pensamento primitivo da criança e do sertanejo, remetendo à realidade de pureza poética que tal pensamento fabrica (RESENDE,1988, p.27).

Como propõe Vânia Resende, em Guimarães Rosa há uma sintonia entre a psicologia do rústico e o modo infantil de ver o mundo. É nessa junção que devemos entender a arte rosiana, apostando no enigma, desafiando a racionalidade, reinventando novas formas de percepção.

$\mathrm{Na}$ concepção lúdica do mundo, a presença do menino é fundamental em alguns textos rosianos, posteriores a Sagarana, como "Campo Geral", obra que faz parte de Corpo de Baile, além de algumas narrativas de Primeiras Estórias.

Em Campo Geral, embora a narrativa seja construída, aparentemente, na terceira pessoa, predomina no texto a percepção de uma criança de oito anos. Há, pois, um narrador de terceira pessoa que sustenta a narrativa, mas que embarca no ponto de vista de Miguilim, que registra, anota, soletra para o leitor o mundo, que se lhe apresenta de modo opaco e míope. Esse mesmo narrador-adulto vai, através da percepção de Miguilim, construindo uma "narrativa de rabiscos", na medida em que esboça um "olhar míope”. Em outros termos, esse olhar está associado a uma percepção poética. Essa visão infantil do menino entra em sintonia com a leitura que ele faz do mundo, leitura que vai sendo apurada à proporção que o garoto começa a soletrar, a decodificar o mundo sertanejo que o rodeia. Podemos afirmar que a percepção infantil de Miguilim é como um rabisco. Como afirma Benjamin, “[...] a criança não se limita a descrever as imagens: ela as escreve no sentido mais literal. Ela as rabisca.'(BENJAMIN, 1987a, p. 242). No final da estória, quando o médico coloca os óculos em Miguilim, essa percepção do real se amplia. Em todo o conto, o leitor tem uma visão de mundo filtrada por essa percepção-rabisco do menino. Nesse sentido, podemos dizer que Miguilim, na sua percepção infantil, vai soletrando a realidade que o rodeia, rabiscando, isto é, recriando poeticamente situações, produzindo novas experiências existenciais ao filtrar retalhos de conversas ouvidas, vozes de animais, superstições e códigos da comunidade. Através da aprendizagem com o irmão Dito e a dura experiência da morte ao perder esse irmão, ao aprender com os vaqueiros, com a mãe, a avó e outros parentes, o menino vai soletrando e reinventando as experiências da comunidade, decodificando o mundo de acordo com sua percepção pueril que, colada à imagem, funde palavra e coisa, dando asas à imaginação sem a mediação da racionalidade. "E outras coisas desentendidas, que o Papaco-o-paco sempre experimentava baixo para si, aquele grol, Mi- 
guilim agora às vezes duvidava que vontade fosse de um querer dizer (Campo geral, p. 125).

Em Primeiras Estórias, há alguns contos que retratam a infância, como As margens da alegria, Os cimos, A menina de lá, Nenhum, nenhuma e Partida do audaz navegante. Em vista das limitações deste trabalho, vamos fazer ligeiras reflexões sobre duas narrativas dessa obra: "As margens da alegria" e "Os cimos".

Em "As margens da alegria", acompanhamos a viagem do menino, que sai de sua crua realidade e, viajando de avião, mergulha no universo do sonho e da imaginação. Quando chega à grande cidade, contempla um peru, que com suas variadas cores, funciona como um brinquedo. Ao contemplá-lo, o garoto sente uma espécie de epifania, de alumbramento:

\footnotetext{
"O peru, imperial, dava-lhe as costas para receber sua admiração (...) Grugulejou, sacudindo o abotoado grosso de bagas rubras e a cabeça possuía laivos de um azul-claro, raro, de céu e sanhaços; e ele, completo, torneado, redondoso, todo em esferas e planos, com reflexos de verdes metais em azul-e-preto-o peru para sempre. Belo, belo !" Tinha qualquer coisa de calor, poder e flor, um transbordamento." (ROSA, 1969, p.4)
}

Essa alegria do garoto é interrompida com a morte da ave para comemorar o aniversário do doutor. Surge um novo peru, mas sem a beleza do primeiro. O menino sente o peso da realidade, mas à noite, ao contemplar um vagalume, em seu tremeluzir de luz esverdeada, constata que o prazer desse alumbramento é como o piscar provisório do inseto. No último conto, Os cimos, o garoto volta à cidade grande e contempla agora um tucano, que também com suas cores ajuda o garoto a superar a ausência da mãe, uma vez que, no primeiro conto, ele já adquiriu uma experiência e aprendeu a conviver com as perdas, ao perceber que o viver tem alternâncias de alegrias e tristezas como o piscar do vagalume ou como o voo do tucano que vai, mas volta. Essa aprendizagem da perda nos faz lembrar o jogo do fort-da de Freud, quando o menino, através do brinquedo, aprende a conviver ativamente com a ausência da mãe.

Sagarana, primeira obra de Guimarães Rosa, traz elementos lúdicos, algumas vezes ligados à infância e que serão reelaborados posteriormente em outras narrativas. Nessa obra, e também em outras, o modo infantil de perceber o mundo entra em sintonia com a psicologia do rústico. Vendo a realidade sob uma perspectiva mágica, intuitiva, sertanejos e crianças reinventam novos olhares alertando-nos para a complexidade do real, no qual ficção e realidade muitas vezes têm tênues limites.

$\mathrm{Na}$ perspectiva do jogar como brincar, podemos entender o porquê de algumas epígrafes de Sagarana se apresentarem atra- 
vés de fragmentos de narrações infantis ou mesmo de alguns provérbios, sem contar a inserção de casos narrados por personagens durante algumas narrativas. Tais recursos direcionam o leitor para a oralidade, funcionando como atividades lúdicas que precederam a palavra escrita. As duas epígrafes que encabeçam Sagarana apontam para o ato de contar. A primeira é uma quadra de desafio: "Lá em cima daquela serral passa boi, passa boiadal passa gente ruim e boal passa a minha namorada". A segunda está em inglês e traz o subtítulo de "estórias para meninos": "For a walk and back again", Said/ the Fox. "Willyou come with me? I'll take you on my back. For a walk and back again." Essas epígrafes nos remetem à palavra oral, reelaborada pelo autor numa tentativa de resgatar elementos lúdicos (afetivos, pulsionais) ligados ao corpo e que se perdem na tradução para o texto escrito. Assim, o contar remete não só ao mito e à invenção, mas também à encenação.

É nessa linha também que devemos entender em Sagarana a presença insistente do jogo do truco na medida em que nessa atividade a palavra falada pode valer mais do que as cartas de cada parceiro. No espaço do sertão, em que a astúcia é fundamental, esse jogo se torna uma variante das estórias infantis, acenando para o faz de conta. Na concepção rosiana do viver como atividade perigosa, é importante fingir ter cartas boas na travessia existencial dos personagens. Dessa forma, o truco tem sintonia com a representação teatral, uma vez que os personagens, através de seu corpo, com seus, olhares e gestos, podem vencer as lidas do sertão, menos pelo valor das cartas e mais pela força da palavra ou até mesmo pelo grito (OLIVEIRA, 1981,p.118).

Em entrevista a Günter Lorenz, o escritor mineiro faz a seguinte declaração:

Eu diria mesmo que, para a maioria das pessoas, e não me excetuo, o cérebro tem pouca importância no decorrer da vida. O contrário seria terrível: a vida ficaria limitada a uma única operação matemática, que não necessitaria da aventura do desconhecido e inconsciente, nem do irracional. (LORENZ, apud COUTINHO, 1983 p. 93)

A partir dessas reflexões, e sem nenhuma pretensão de esgotar a temática lúdica na escrita rosiana, vamos destacar aqui algumas passagens de Sagarana. Se para Rosa, "viver é perigoso", espécie de mantra freqüente em Grande Sertão: veredas, naturalmente esse viver supõe o encontro com o desconhecido. A vida é um perigo porque pode ser concebida como um jogo imprevisível em que bem e mal estão misturados. Nessa perspectiva do viver como jogo arriscado, é interessante observar que a viagem é um dos temas estreitamente relacionados ao lúdico. Benedito Nunes rastreou o motivo da viagem em algumas 
narrativas rosianas, mostrando como o deslocar está ligado à lúdica concepção de sertão:

Nesse sentido, o sertão de Guimarães Rosa coloca-se no mesmo plano da Mancha de Cervantes e da Dublin de Joyce. É o espaço que se abre em viagem, e que a viagem converte em mundo. Sem limites fixos, lugar que abrange o perto e o longe, o que a vista alcança e o que só a imaginação pode ver (NUNES,1976, p. 174).

O mesmo crítico afirma ainda que não só em Sagarana, mas em outras obras como Corpo de Baile e Grande Sertão: veredas, a imagem do "destino itinerante se constrói com lances aleatórios de jogo ou com os circunlóquios de uma fortuna andeja" (NUNES, 1976, p. 177).

Na primeira obra rosiana - Sagarana - podemos encontrar a presença do jogo em vários contos. Vamos destacar apenas algumas narrativas, mas é possível encontrar um discurso lúdico em todos os contos do livro (OLIVEIRA, 1981). Em muitas dessas estórias, jogo e viagem se fundem. Assim ocorre no conto "O burrinho pedrês". Um dos nomes desse animal- protagonista é Sete-de-Ouros, quarta carta de baralho do jogo de truco, jogo este frequente no sertão mineiro. Já velho e aposentado, o burrinho é escolhido pelo Major Saulo para acompanhar uma boiada juntamente com outros cavalos mais ágeis. Como uma carta de baralho, o animal é repassado por vários vaqueiros, que o desprezam. No final da narrativa, ele é cavalgado por Badu. Já tonto Badu entra montado em Sete-de-Ouros no Riacho da Fome, que transbordou com a enchente, matando vários vaqueiros, que regressavam da cidade, após terem conduzido uma boiada. Pela força do acaso, salvam-se Badu e Francolim. Este consegue sair da enchente agarrado ao rabo do animal; aquele firmando-se nas crinas do burrinho, que surpreende os vaqueiros, já que era tido como imprestável e velho.

Nessa narrativa, outros elementos lúdicos surgem: há um desentendimento entre Silvino e Badu, causado pela disputa de uma namorada. Os vaqueiros temem um assassinato no trajeto da boiada, o que não ocorre. Essa tensão é neutralizada na estória, rompendo com a expectativa do leitor. Outro fato inesperado: o burrinho, já velho, é ridicularizado pelos vaqueiros, que não acreditam em sua capacidade. No final da estória, ele não só consegue cumprir o trajeto, como salva dois vaqueiros da enchente. Interessante é notar que o burrinho tem um "pezinho de borralheira": "Sete-de-Ouros, uma das patas meio flectida, riscava o chão com o rebordo do casco desferrado, que lhe rematava o pezinho de Borralheira". (ROSA, 1976, p. 5). Essa passagem permite uma aproximação da narrativa com a história infantil A Gata Borralheira. A personagem, como o 
burrinho, é humilhada por todos, tornando-se depois princesa. No caso do animal, seu momento de brilho se dá no final quando salva dois vaqueiros. Como podemos perceber, traços lúdicos como a tensão (a possível morte de Badu por Silvino), ou a presença do inesperado e do acaso apontam para uma percepção lúdica da realidade, percepção esta que dialoga com o universo do faz-de-conta, tão freqüente na visão de mundo dos jagunços rosianos.

Podemos encontrar também várias digressões no conto, que é descrito de modo fragmentado. Estamos diante de um narrador lúdico que corta sua estória algumas vezes e permite que outros vaqueiros funcionem como narradores secundários, contando vários casos: o caso do boi Calundu, narrado por Raymundão, a estória do pretinho, que espantou a boiada, além das quadras populares cantadas pelos vaqueiros. Tudo isso é tecido por Rosa através de uma prosa poética inebriante, ao mesmo tempo em que ele resgata a oralidade como forma lúdica e arcaica do contar. Em O Burrinho Pedrês há uma diferença entre o narrador principal, que exterioriza as descrições e os narradores secundários que, interiorizando e dramatizando as estórias, acenam para a oralidade no ato de contar. Outras vezes, ludicamente, como um curinga do baralho, o narrador de O Burrinho pedrês finge sair de cena, como se posicionasse no lugar do leitor, como se ouvisse os casos dos vaqueiros. Percebemos que esse narrador não tem pressa de contar como se convidasse o leitor a entrar num gozo de linguagem, através de longas descrições dos bois e da paisagem:

No conto de Guimarães Rosa, a história central, do burrinho, é intermitente: a todo momento é interrompida por longas descrições da boiada e por episódios vividos pelos vaqueiros, como a rivalidade amorosa entre Badu e Silvino, o plano de um crime de morte, a luta de Badu com o zebu atiçado por Silvino etc(LEÃO, 1973, p. 250).

O ludismo persiste, nesse primeiro conto de Sagarana, até mesmo na própria linguagem através do uso de aliterações e assonâncias, dos paralelismos e elipses, das pausas, síndetos e polissíndetos, enfim, nota-se, principalmente em trechos de prosa poética, às vezes até metrificada, um ludismo que provém não apenas do significado, mas também da sonoridade e do ritmo dos significantes: "Boi bem bravo, bate baixo, bota baba, boi berrando... dansa doido, dá de duro, dá de dentro, dá direito...Vai, vem,volta, vem na vara, vai não volta, vai varando..." (ROSA, 1976, p. 24).

Contando casos, cantando quadras, os vaqueiros desse conto tornam mais suave o pesado trabalho de tanger a boiada na viagem para o sertão. Vale ressaltar, insistimos, que a própria viagem já é lúdica, na medida em que supõe o encontro com o inesperado e a transposição de diversos obstáculos. 
Outra narrativa lúdica marcada pela viagem é o conto O duelo. Turíbio Todo, quando foi pescar, encontrou a mulher com outro, Cassiano Gomes. Abandonou a casa em silêncio, comprou antes uma boa besta, ótima espingarda e, vendo o suposto rival numa janela, matou-o. $\mathrm{Na}$ verdade, ele assassinou o irmão de Cassiano, Levindo Gomes. Cassiano vai ao encalço do assassino para vingar Levindo. A narrativa é construída através de um jogo em que cada rival tenta surpreender o outro em pleno sertão. Turíbio tem razão, mas Cassiano também, uma vez que teve o irmão assassinado. Os dois duelistas chegam a trocar de animais, sem saber. Em outras passagens, o jogo é construído através do espaço, tecido pela astúcia geográfica planejada pelos desafiantes. Os deslocamentos dos personagens são descritos através do mover do baralho. A fim de enganar o inimigo Cassiano, Turíbio Todo:

\footnotetext{
"fez que vinha e não veio, e fez como o raposão. Obliquou a rota, para nor-nordeste, demandando as alturas do Morro do Guará ou do Morro da Garça, e aí houve que foi onde Cassiano tinha descalculado, mancando a traça e falseando a mão.- Tem tempo... - disse. E continuou a batida, confiado tão só na inspiração do momento, porquanto o baralho fora rebaralhado e agora tinham ambos outros naipes a jogar ( ROSA, 1976, p. 146).
}

No final da narrativa, novamente surge, como no conto $\mathrm{O}$ burrinho pedrês, o acaso. Cassiano não consegue matar Turíbio porque este sai da raia, indo para São Paulo: "Que bom, poder ficar livre de tantas canseiras... "Es-te den-tro e es-te fora!... Turíbio Todo tinha pulado fora da roda, e não mais brincou"... (ROSA, 1976, p. 158). Quando volta, ele é assassinado por um franzino e pacato capiau, Vinte-e-Um, cujo filho havia sido salvo por Cassiano Gomes, que pagou um médico para curar o menino. Antes de morrer, o rival de Turíbio pediu que o capiauzinho lhe prometesse que mataria o inimigo. $\mathrm{O}$ nome do capiau é lúdico e acena para um jogo de cartas, vinte e um. Desse modo, o aliado de Cassiano elimina Turíbio, como se completasse a pontuação da partida desse jogo, pagando assim sua promessa. Outros personagens da narrativa funcionam como parceiros nessa disputa lúdica: a esposa de Turíbio recebe cartas do marido e lhe dá informações que oscilam entre a verdade e a mentira, o mesmo fazendo com Cassiano. Outro parceiro nesse jogo é Chico Barqueiro que,desconfiado, fica indeciso na disputa transportando em sua balsa, ora um ora outro duelista, permanecendo neutro na contenda.

Nesse duelo, não há ganhador nem perdedor: Turibio matou por engano Levindo Gomes, mas é morto por Vinte-e-Um, compadre de Cassiano. Este não vinga o irmão; morre do coração, morte provocada indiretamente pelo cansaço da persegui- 
ção, alimentada por Turíbio, que sabia que ele era cardíaco. No entanto, indiretamente, Cassiano cumpre sua vingança através de Vinte-e-Um. A narrativa explora as tensões e os vaivéns dos desafiantes são costurados por um leve humor, produzido por um quase encontro que nunca se dá e que é nutrido por vários parceiros, moradores e informantes do sertão, nesse jogo que não se fecha. Em uma conversa com Cassiano, referindo-se à disputa dos dois, um personagem secundário, que troca fogo com ele por engano, afirma: "Até costumava perguntar sempre aos viajantes (...) se o "truco fecha" (ROSA, 1976, p. 154, grifo nosso). E o imprevisível também ocorre nessa narrativa. Da mesma forma que o velho burrinho, no primeiro conto, surpreende ao completar a viagem e salvar os vaqueiros, em $\mathrm{O}$ duelo, encontramos um homem franzino, com traços infantis, que subitamente mata o valente Turíbio, quando este voltava de São Paulo, seguro de si, uma vez que o rival Cassiano havia morrido. A imprevisibilidade da morte de Turíbio está em perfeito diálogo intertextual com a epígrafe do conto, que traz um diálogo, provavelmente retirado do anedotário popular. Nesse diálogo a piranha, conversando com a arraia, se gaba de seus dentes de navalha. Sua interlocutora lhe responde que também tem uma arma poderosa, o ferrão a prumo. O gimnoto mole se intromete na conversa e afirma que se soltar "três pensamentos elétricos", mata as duas. Piranha e a arraia corresponderiam a Turíbio e Cassiano, cada um mostrando suas armas. O gimnoto poderia ser associado a Vinte-e-Um, que, na sua moleza, aparentemente não tem força, mas é capaz de eliminar Turíbio.

O conto Minha Gente traz um tablado com peças de xadrez na primeira página, o que aponta para um tipo de jogo que remete à racionalidade. No final da estória, as racionais previsões desse jogo são dissolvidas. Santana, amigo do personagem-narrador, vence a partida de xadrez, que espelha o desenrolar da narrativa. $\mathrm{O}$ acaso acaba predominando, com o casamento do personagem-narrador com Armanda, surpreendendo assim o leitor, que esperava vê-lo casado com Maria Irma, prima e "namorada de brinquedo" do doutor (ROSA, 1976, p.74). A epígrafe do conto ("Tira a barca da barreiral deixa Maria passar/ Maria é feiticeira/ ela passa sem molhar.") - apresentada como "Cantiga de treinar papagaios"- acena para a oralidade, para o falar espontâneo, repetitivo, em que o significante conta mais do que o significado. A feiticeira da epígrafe remete à magia, contrastando com as previsões de todo jogo de xadrez, mais voltado para a lógica. Nesse sentido, o tablado de xadrez, remetendo à racionalidade, funciona como signo invertido, já que a experiência ligada ao mágico tem mais sintonia com a imaginação e com o mistério. Há outros elementos lúdicos na estória. Entre José Malvino e o doutor, ou seu parceiro de xadrez, Santana, outro companheiro de viagem do personagem-narrador, 
que viaja rumo à fazenda, há uma oposição: José representa o homem lúdico, sertanejo que age mais pela intuição do que pela razão: "José, você é um companheiro de primeira, porque não tem a mania de jogar xadrez..." E Malvino responde: Bondade sua, seu doutor... só que eu nem não sei que buzo é esse..." ( ROSA, 1976, p. 179). Vale ainda mencionar, como marcas do jogo nessa narrativa, as contraditórias e astutas alianças dos políticos do interior, formando "uma trapizonga em estabilíssimo equilíbrio” ( ROSA, 1976, p. 188). Outra passagem lúdica e saborosa dessa narrativa é a aposta entre o personagem-narrador e o moleque Nicanor, que lhe garante pegar o cavalo Vira-Saia sem milho nem cabresto. Nicanor acaba vencendo a contenda e o doutor tem de lhe pagar dois mil reis, além de uma quantia extra para quitar o chicote que ele perdeu, sem contar a esmola que terá de dar às almas do Purgatório, promessa que fez se achasse o rebenque.

A estrutura de Minha Gente está em total oposição com o tablado de xadrez, ostentado na primeira página da narrativa. A narrativa não tem linearidade, assemelhando-se assim ao conto O burrinho pedrês. Minha Gente é um texto constituído de flashes, pequenos casos, quadras, comentários sobre táticas do xadrez, fragmentos do cotidiano de uma fazenda, num ritmo moroso, lembrando-nos a vida pacata do sertanejo, pessoa sem abstração, afeita à intuição, voltada muito mais para as estórias do que para a continuidade da História. Nesse sentido, os matutos e as crianças têm tanta sabedoria quanto os doutores da cidade, já que aqueles, anteriores à lógica, conseguem perceber pela imaginação o supra-senso da vida. .

Outra narrativa lúdica é A volta do marido pródigo. Paródia do filho esbanjador do Evangelho, que gasta tudo e é perdoado pelo pai, Lalino é um bom-vivant. Não gosta de trabalhar e adora uma boa prosa. Após folhear umas revistas, que traziam belas mulheres do Rio, o protagonista sonha em viver na cidade grande. Abandona a esposa,vende o que tem, pede dinheiro emprestado ao espanhol Ramiro. Depois de alguns meses, sua mulher vai morar com o mesmo espanhol, que the havia feito um empréstimo para viajar. Sem dinheiro na capital, Lalino volta para sua cidade, torna-se cabo eleitoral do Major Anacleto, que vence as eleições. $O$ protagonista acaba se reconciliando com a esposa e os espanhóis são expulsos da região.

Lalino é um nome significativo. Vem de lalo, palavra derivada do grego - lalein - que significa falar, tagarelar. Com sua palavra, o mulato conquista as pessoas. Vive no mundo da fantasia e da representação: mente, dribla seu chefe com conversa fiada para não trabalhar, é cordial com os companheiros, recebendo vantagens com seus agrados. Pode-se afirmar que Lalino representa, como um ator. Há uma passagem do conto em que o protagonista inventa uma peça -O Visconde Sedutor - seduzindo 
seu chefe, que não percebe que ele está ocioso: “- Falar nisso, seu Marrinha, eu me alembrei hoje cedo de outro teatrinho, que a companhia levou, lá no Bagre: é o drama do "Visconde Sedutor"... vou pensar melhor, depois lhe conto. Esse é que a gente podia representar..." (ROSA, 1976, p. 72.) Como o visconde da peça que ele mesmo inventa, Lalino seduz pela palavra, engana os outros com sua tagarelice, enfim, faz encenações sem ser odiado. Essa capacidade de viver mais no plano da fantasia do que no da realidade pode ainda ser comprovada quando o mulato resolve ir para o Rio de Janeiro vivenciar as fantasias que criara ao contemplar mulheres de almanaques e revistas: " $\mathrm{E}$ Lalino buscava as figuras e fotografias de mulheres. É, devia de ser assim... Feito esta. Janelas com venezianas... ruas e mais ruas com elas... (ROSA, 1976, p. 82)

Essa intertextualidade com o teatro e com o faz-de-conta está ainda sintonizada no conto com um caso do folclore brasileiro, encaixado no texto rosiano: a história do sapo que vai para o céu na viola do urubu e acaba enganando São Pedro, fingindo que não sabe nadar e pedindo para cair na pedra. São Pedro o lança na água, exatamente onde queria ficar. Lalino, na sua astúcia, é como o sapo que mente. Driblando todos com suas conversas e encenações, age como um homem lúdico, vivendo mais no plano da representação. É exatamente essa capacidade de seduzir pela palavra e de encenar que leva o Major Anacleto a contratá-lo como cabo eleitoral na eleição da qual sai vencedor: "Um mulato desses pode valer ouros", afirma Tio Laudônio sobre a importância de Lalino nas eleições (ROSA, 1976, p. 98, grifo nosso).

No conto São Marcos, o personagem-narrador, representante da cultura erudita e racional, ofende João Mangolô. Este, para vingar-se, faz um feitiço para atingir o doutor: coloca uma tarja preta no retrato dele, cegando o à distância, fazendo com que o protagonista se desorientasse na floresta. Perdido, com muito custo, o personagem-narrador consegue chegar à casa do bruxo e, lutando contra ele, reza a oração de São Marcos, voltando a enxergar. Nesse conto há ainda uma disputa poética entre Quem-será e o personagem-narrador. Esses desafiantes escrevem, em passeios alternados, poemas nos colmos de bambus. No final da contenda, o narrador-personagem coloca nos bambus nomes de reis assírios, que segundo os historiadores, cegavam os inimigos de guerra. Temos assim, nessa disputa, a palavra poética funcionando como índice da narrativa, antecipando a cegueira do doutor na mata, no final da estória. Além disso, a escrita desses soberanos nos bambus pode apontar ainda para um gozo da linguagem, já que nesse jogo de significantes, segundo o protagonista, as palavras têm canto e plumagem, independente do significado que transmitem.

Merece destaque na narrativa a relação entre cegueira e visão, metáforas da disputa entre ciência e magia. O doutor, re- 
presentante do saber científico, está associado ao ver; já o feiticeiro estaria relacionado à cegueira. Duvidando das bruxarias, o doutor ofende Mangolô e recebe como troco a cegueira através do feitiço do bruxo. No final da estória, o doutor, que duvidava das atividades mágicas, para vencer seu rival, acaba dando a mão à palmatória, recorrendo à magia e rezando a oração de São Marcos, recobrando assim a visão. Esse doutor, que acompanha poeticamente a paisagem com seu binóculo, ao ficar cego com o "trabalho" de Mangolô, descobre que o pior cego é o que não quer ver. Só mesmo após a cegueira é que o personagem-narrador passou a "enxergar" mais, ao reconhecer outras formas pré-lógicas de percepção da realidade.

Desse modo, o conhecimento intuitivo se apresenta de modo tão válido quanto o racional: o culto protagonista só vence a contenda com o bruxo, usando uma arma "mágica", a oração de São Marcos. E o interessante é que, ao recitar a oração, é a palavra oral que leva o protagonista a enxergar novamente. Merece ainda destaque, em algumas passagens da narrativa, a intensa sonoridade das palavras e a sedução que a natureza exerce sobre o personagem-narrador. A frase adquire um ritmo de prosa poética, principalmente nas descrições da floresta, apresentada como um espaço encantador e lúdico, antecipando o final do conto, quando se nota a adesão do doutor a um saber "primitivo", ao recitar a oração de São Marcos, evidenciando assim o valor da magia diante da abstração racional:

(...) Mas cumpria com a lista, porque eu não podia deixar o povo saber que eu entrava no mato, e lá passava o dia inteiro, só para ver uma mudinha de Cambuí a medrar da terra de-dentro de um buraco no tronco de um camboatá; para assistir à carga frontal das formigas-cabaças contra a pelugem farpada e eletrificada de uma tatarana lança-chamas; para namorar o namoro dos guaxes, pousados nos ramos compridos da aroeira, para saber ao certo se o meu xará joão-de-barro fecharia mesmo a sua olaria, guardando o descanso domingueiro; para apostar sozinho, no concurso de salto-à-vara entre os gafanhotos verdes e os gafanhões cinzentos, para estudar o treino de concentração do jaburu acromegálico; e para rir-me à glória das aranhas-d'água, que vão corre-correndo, pernilongando sobre a casca de água do poço, pensando que aquilo é mesmo chão para se andar em cima. (ROSA, 1976, p. 28)

Racionalidade e intuição, pensamento lógico e pré-lógico se presentificam na relação entre homem e animal, adulto e criança no conto Conversa de bois. E nessa relação, a percepção infantil e lúdica do mundo dialoga com a percepção do animal. $\mathrm{Na}$ conversa dos bois, há uma estória que é contada paulatinamente por eles: trata-se do caso do boi Rodapião. Ele pensa excessivamente e muitas vezes por silogismo: "Todo boi é bi- 
cho. Nós todos somos bois. Então, nós todos somos bichos!... Estúrdio..." (ROSA, 1976, p. 306) Negando a animalidade, sua lógica o leva à morte: segundo ele, se em morro há água, há também bom capim. Buscando pasto melhor, Rodapião sobe a um morro e acaba rolando do alto. A racionalidade de Rodapião o diferencia dos outros bois, fazendo com que ele se aproxime mais do mundo do adulto, representado pelo carreiro Agenor Soronho. Este é amante da mãe do garoto Tiãozinho, que o odeia. Tiãozinho representa a impotência diante do mando de Soronho, usurpador da posição do pai, cujo corpo está sendo levado pelo carreiro no meio das rapaduras. Assim, é possível fazer uma aproximação da percepção do garoto - visto pelos bois como "homem-bezerro" - com a do animal. O menino deseja a morte do carreiro e, em seus devaneios, sente-se enorme e poderoso, o mesmo acontecendo com os bois:

\footnotetext{
Eu, Tiãozinho!... sou grande, sou dono de muitas terras com muitos carros de bois, com muitas juntas... Ninguém pode mais nem falar no nome do seu Soronho... Não deixo!... Sou o mais forte de todos... Ninguém pode mandar em mim!... Tiãozão... Tiãozão!...Oung...Hmong...Mûh!.. (ROSA, 1976, p. 320) (Grifo em itálico do autor).
}

Evidentemente não se deve ler a morte de Soronho como uma mera vingança do menino ou uma simples vitória da ilogicidade sobre a razão. No mundo rosiano, "tudo é e não é". O menino na sua pureza se aproxima da percepção do animal, mas tem também seu lado mal, uma vez que deseja a morte do carreiro. No caso dos bois ocorre o mesmo: Rodapião é boi, mas ao negar sua animalidade tem algo de humano. Tiãozinho é "homem-bezerro" da mesma forma que Soronho tem um lado animalesco nas agressões constantes que faz ao garoto. O que merece ser destacado é que animalidade e humanidade se misturam através das fantasias do menino com a dos bois. Ao se sentirem enormes e poderosos, essas fantasias acabam se corporificando, tornando-se ato na parcial decapitação do carreiro. A morte do carreiro, como a morte do boi Rodapião, representa a derrota da visão lógica do mundo e uma aposta na instintividade ou em formas pré-lógicas de experiência do real, nas quais se podem inserir tanto o artista quanto a criança.

No último conto de Sagarana, A hora e a vez de Augusto Matraga, é possível destacar vários elementos ligados ao ludismo. Nhô Augusto é muito rico e gosta de jogar o truco nas horas de folga. Pouco a pouco vai perdendo tudo: a esposa Dionora, a filha Mimita, boa parte das terras, os jagunços que lhe prestavam serviço. Espancado pelos próprios bate-paus, que foram trabalhar para o fazendeiro inimigo, porque o patrão não pagava em dia, Matraga é jogado numa ribanceira. Recolhido por um casal de pretos, converte-se e passa a ter uma vida 
de penitência afirmando que sua hora e sua vez há de chegar. O jogo de truco perpassa pelo texto em algumas passagens. Em um dos trechos, já convertido, Matraga afirma a Mãe Quitéria, a preta que o acolheu após o espancamento, que já foi "zápede de feira". O zápede é a carta maior do truco. Se antes, Augusto Esteves estava jogando do lado do mal, após a conversão, passa a fazer o jogo do bem, mas com outros naipes. Mas a estória não termina nesse dualismo maniqueísta. $\mathrm{O}$ texto se fecha com um duelo em que Matraga, convertido, lança mão de seu lado violento, já domado pela conversão, para salvar uma família. O chefe dos cangaceiros, Joãozinho Bem-Bem, teve um de seus homens morto à traição e queria acertar as contas com toda a família, já que o assassino fugira. Trava-se paradoxalmente um duelo cristão: Matraga mata Bem-Bem e é morto por ele. Os duelistas se perdoam e a oposição bem e mal se dissolve, como no romance Grande Sertão: veredas: na luta entre Deus e o demo, as coisas se misturam. É na travessia existencial, mediada pelo jogo da linguagem, que cada um traça a sua trajetória, já que as escolhas do homem dependem também da sua ação, tudo isso porque bem e mal não estão nem de um lado nem de outro, mas na tensão entre eles, como afirma Riobaldo no final de Grande Sertão: veredas: "Existe é homem humano. Travessia".

Com relação à conversão de Matraga, vale aqui destacar um lado "ingênuo" que tem sintonia com uma das epígrafes. No primeiro paratexto lê-se: "Eu sou pobre, pobre, pobre/ vou-me embora, vou-me embora/..../ Eu sou rica, rica, rical vou-me embora, daqui..." (Cantiga antiga). Essa aparente ingenuidade remete ao mundo infantil que perpassa pelo conto. Pouco depois de ser recolhido pelo casal de pretos, já em processo de conversão, Matraga se lembra de sua infância: “(...) Também não rezou. Porém a luzinha da candeia era o pavio, a tremer, com brilhos bonitos no poço de azeite, contando histórias da infância de Nhô Augusto, história mal lembradas, mas todas de bom e bonito final." (ROSA, 1976, p. 338). Seria interessante relacionar esse lado "ingênuo" e "infantil” que acompanha Matraga em sua conversão.

A pesquisadora Walnice Nogueira Galvão estudou a simbologia da marca que Matraga traz em seu corpo, um triângulo inscrito em uma circunferência, marca de ferro que foi impressa na coxa direita do protagonista a mando do Major Consilva. (GALVÃO, 1978, p. 57). Após fazer referências a vários sinais e estigmas em corpos de santos e místicos da Igreja católica, a pesquisadora demonstra que a marca de Matraga tem relação com a estrutura da narrativa. O círculo está relacionado à trajetória circular empreendida pelo protagonista, que sai do Murici e acaba morrendo próximo a essa região, voltando assim ao seu ponto de origem. Também o triângulo aponta para as diversas situações ternárias vivenciadas pelo protagonista, que tem três nomes - Augusto Esteves, Augusto Matraga e Nhô Augusto. 
Além disso, ele forma alguns triângulos na narrativa. Na família há três componentes, Nhô Augusto, Dionora e a filha Mimita. Com o casal de pretos também constrói outro triângulo: mora em três lugares, Saco-da-Embira, perto do Murici, Tombador e novamente um lugarejo bem perto do Murici, o arraial do Rala-Coco, local de onde saíra.

A partir dessa marca no corpo do protagonista, estudada por Galvão, seria interessante destacar aqui algumas conexões entre a "ingenuidade",uma certa "loucura" , o jogo e a religiosidade de Matraga. Ao ser lançado no abismo pelos jagunços do Major Consilva, o protagonista fica meio perturbado das idéias: "O corpo estava estragado, por dentro, e mais ainda a idéia. E tomara um tão grande horror à suas maldades e aos seus malfeitos passados, que nem podia se lembrar; e só mesmo rezando.” (ROSA, 1976, p. 340). Convertido, Matraga se torna uma espécie de "bobo de Deus", expressão atribuída à figura de São Francisco de Assis. Ser "bobo de Deus" significa ser puro, despojado, ter alma de criança. Para entrar no céu, segundo o Evangelho,é preciso se tornar um menino. Essa pureza de alma está freqüente no protagonista após sua conversão. E Matraga entra no duelo com Joãozinho Bem-Bem com uma alegria e serenidade que lembra os mártires da igreja ao enfrentarem a morte. Como afirma Galvão, "a alegria de Matraga durante toda a cena final é a alegria dos mártires, da alma que, enfrentando a provação, reconhece que está prestes a integrar-se em Deus, passando pelo sacrifício do corpo" (GALVÃO, 1978, p. 66).

Pode-se dizer que Matraga renasce ao se converter e enfrenta a morte numa espécie de "santidade" quase infantil. Prova disso é que há um paradoxal duelo cristão: Matraga morre e mata o chefe dos cangaceiros. Os dois duelistas se perdoam porque querem ir para o céu: “- Feito, meu parente, seu Joãozinho Bem-Bem. Mas, agora, se arrepende dos pecados, e morre logo como um cristão, que é para a gente poder ir juntos..." (ROSA, 1976, p. 364).

Se antes, como filho de fazendeiro, Matraga sempre vencia no jogo da vida, sendo o truco uma metáfora dessa vitória, ao se converter ele passa “(...) umas rodadas sem jogar (...)”. (ROSA, 1976, p. 333). Ao se tornar "bobo de Deus", ele acaba jogando de outra forma. É nesse sentido que podemos entender uma das epígrafes da canção infantil ( Eu sou pobre, pobre, pobre... eu sou rica, rica, rica...). Pobre, sem família, machucado por dentro e por fora, ele se vê como espiritualmente rico. No entanto, não devemos entender essa conversão do protagonista apenas como um caminho em direção ao bem. Na verdade, por trás dessa religiosidade sublimada, existe um Matraga que não perdeu o seu lado jagunço e violento, enfrentando o chefe dos cangaceiros com coragem e agilidade. Dessa forma, nesse "duelo cristão", é importante perceber a visão dialética rosiana em que bem e 
mal, pureza e astúcia, logicidade e loucura, santidade e jagunçagem se fundem. As coisas estão em constante movimento. Daí a segunda epígrafe do conto, que mostra ser o pulo do sapo não uma boniteza, mas necessidade: Sapo não pula por boniteza, mas porém por percisão." ( Provérbio capiau ).

Além dos contos de Sagarana, outras narrativas fazem referência ao lúdico. Na novela Buriti, a trama do desejo se espelha no jogo de bisca entre os personagens Nhô Liodoro, Lalinha, Glória,Miguel e Nhô Gualberto. O ludismo adquire ainda uma sofisticação muito grande na última obra Tutaméia, livro de contos, permeado por quatro prefácios e quarenta narrativas que devem ser lidos num jogo em que personagens e frases de uma estória são relançados em outras. Como já mostrou Vera Novis, (NOVIS, 1989), as narrativas se constroem num constante deslocar, formando um caleidoscópio de palavras, com personagens e motivos que se espelham e se interconectam no último conto - Zingaresca - espécie de painel de personagens de todo o livro. Surge assim uma escrita nômade, tecida de fragmentos de estórias que se remetem num jogo de significantes, em que a dança e o som das palavras, com seus cantos e plumagem, formam uma orquestra afinada.

Como esperamos ter demonstrado, a concepção rosiana de mundo, tecida no jogo, está em sintonia com a concepção de infância, enfocada principalmente na visão agambeniana. Através do lúdico, somos capazes de inventar e podemos resgatar em nossas existências fortes experiências descartadas pelo pensamento lógico da modernidade. Assim, Rosa nos oferece o acaso, a incerteza, o mito, as histórias infantis e as narrativas populares como formas ativas de construção do sujeito na História. Acompanhando o filósofo italiano, se é na infância que o ser humano se constitui, já que é o único animal falante, pode-se dizer que é no jogo da linguagem que Rosa vai transformando a língua em discurso. Sendo seres inacabados, necessitamos não apenas da razão e da história, mas da estória e da magia, já que para Guimarães Rosa o mundo começou com o "era uma vez". E fechamos nosso trabalho com uma frase de Sagarana: "Era uma vez, era outra vez no umbigo do mundo um burrinho pedrês" (ROSA, 1976, p. 48). 


\section{Referências}

AGAMBEN, Giorgio. Infância e história: destruição da experiência e origem da história. Trad. Henrique Burigo. Belo Horizonte: UFMG, 2005.

BENJAMIN, Walter. Magia e técnica, arte e política: ensaios sobre literatura e história da cultura. 3. ed. Trad. Sérgio Paulo Rouanet. São Paulo: Brasiliense, 1987a.

CHAVES, Flávio Loureiro. O brinquedo Absurdo. São Paulo: Polis, 1978.

DUFLO, Colas. O jogo: de Pascal a Schiller. Porto Alegre: Armed, 1999.

GALVÃO, Walnice Nogueira. Mitológica rosiana. São Paulo: Ática, 1978.

HUIZINGA, Johan. Homo Ludens: o jogo como elemento da cultura. $5^{a}$ ed. São Paulo: Perspectiva, 2007.

LEÃO, Ângela Vaz. O ritmo em "o Burrinho pedrês. In COUTINHO, Eduardo. Guimarães Rosa. Rio de Janeiro: Civilização Brasileira, 1983.

LOPES, Benita La sada. A teoria do jogo e a psicanálise. HTTP:/ / escolaletrafreudiana. Com.brleserfiles/110/files/ carteis2007/ carteis2007.05.pdf

NOVIS, Vera. Tutameia: engenho e arte. São Paulo: Perspectiva, 1989.

NUNES. Benedito. O dorso do tigre. São Paulo: Perspectiva: 1976.

OLIVEIRA, Edson Santos de. O discurso lúdico de Guimarães Rosa em Sagarana. Belo Horizonte-Faculdade de Letras, 1981 [Dissertação de Mestrado].

RESENDE, Vania Maria. O menino na Literatura Brasileira. São Paulo: Perspectiva, 1988.

ROSA, João Guimarães. Primeiras Estórias. Rio de Janeiro: José Olympio, 1969.

- Sagarana. Rio de Janeiro: José Olympio, 1976.

Tutameia. Rio de Janeiro: José Olympio, 1976. Manuelzãa e Miguilim: corpo de baile. $11^{\mathrm{a}}$ ed. Rio de

Janeiro: Nova Fronteira, 2001. 
SPERBER, Suzi. Oralidade e pulsão da fição. < http:/ / www.brasa. org/sitemason/ files;160zpmSperber\%20suzi\%frankl.pdf>

VELOSO, Rosãngela Ramos y SÁ. Reflexões sobre o jogo: conceitos, definição e possibilidades. <www.efportes.com/efd132/reflexõessobre-o-jogo.htm>

VIGOTSKY, L. S Pensamento e linguagem. Lisboa: Edições Antídoto, 1979. 